notion, and even go farther with the inference that the Arctic Culture not only reached our eastern coasts, but indeed, penetrated considerably inlandat least in the northern areas of Britain.

\section{Corrosion in Steel Chimneys}

In the last twenty years, developments in the size and efficiency of boiler plants have led to the abandonment of huge masonry chimneys serving a number of boilers in favour of a separate chimney for each boiler. In Engineering of September 12, Mr. A. V. Staniforth shows that this has been brought about not only for the sake of the advantages accruing during overhaul and repair from such sectionalizing, but also because the very large units, now common, call for much larger chimney areas. The normal chimney was built of lapped riveted plates, but corrosion was found to be very rapid. At one large power station, five steel stacks, each $7 \mathrm{ft} .6$ in. in diameter by $80 \mathrm{ft}$. high, constructed of $\frac{3}{8}$-in. mild steel plates riveted together, had corroded away in parts to paper thickness in five years in spite of annual internal and external cleaning and painting. In all cases the corrosion had become most serious at, and had undoubtedly started from, the joint laps and rivet heads, and was most marked in the upper parts of the chimney. The temperature of the gas entering the chimneys was about $250^{\circ} \mathrm{F}$., at which the steel temperature, particularly near the top of the chimney, often fell below dew point, especially during the colder periods of the year. This caused the deposition of moisture, sometimes increased by rainfall. Combining with the sulphurous gases, it formed sulphurous acid which attacked the steel. The moisture running down the chimney collected along the joint laps and rivet heads, and thus was responsible for the especially severe corrosion at these points.

In solving the problem it was considered desirable first to eliminate the points of corrosion, namely, the lapped joints and rivets, and secondly to find some type of lining which would afford adequate protection to the steel plates. Modern developments in electric welding suggested the use of welded butt joint chimneys, which are easy to construct and give a smooth parallel barrel free from all foci for corrosion. In protecting the interior of the chimney plates from corrosion, asbestos sheeting of certain types was found reasonably suitable. The five steel stacks mentioned above were replaced by lined stacks in 1935 , and five years later a section of the lining was removed from one of the stacks. It was then found that no corrosion of any kind had taken place and that the mill scale was still on the steel. Another advantage is that the heat-insulating effect of the lining cuts down the heat loss, and so the period during which the temperature of the steel falls below the dew-point is very much reduced. Tests showed that with a gas temperature of $290^{\circ} \mathrm{F}$., the outside temperature of an unlined stack was $210^{\circ} \mathrm{F}$., while the lined stack had an outside temperature of $150^{\circ} \mathrm{F}$. The lower outside temperature of the stack reduces considerably the cost of maintenance of the outside of the chimney by increasing the life of painting.

\section{Health of Hawaii}

According to the report of the Board of Health of Hawaii for the fiscal year, the lowest death-rate ever recorded for these islands, namely, $7 \cdot 18$ per 1,000 inhabitants, occurred in 1940. There were 3,025 deaths in a population of 423,332 , the chief causes being heart disease, cancer, congenital malformation and disease, tuberculosis and nephritis. Pneumonia dropped from the second to the eighth leading cause of death, a fact which was attributed to the use of serum and sulphapyridine, which were distributed free to practitioners for the medically indigent. The birthrate was $22 \cdot 62$, as compared with $21 \cdot 79$ in 1939 . An outbreak of 101 cases of infantile paralysis with 10 deaths occurred during the year. The death-rate from tuberculosis was $63 \cdot 2$ per 100,000 , the lowest on record. There were 56 cases of typhoid fever, which were attributed principally to carriers; no cases were traced to milk or to the potable water. There were 77 cases of typhus with 1 death. There were 1 case of human plague which ended fatally and 47 cases in rodents as compared with 129 the previous year.

\section{Announcements}

The Lister Medal for 1942, which is given in recognition of distinguished contributions to surgical science, has been awarded to Prof. Evarts A. Graham, professor of surgery in Washington University, and he will deliver the Lister Memorial Lecture in 1942, or later, under the auspices of the Royal College of Surgeons of England. This is the seventh occasion of the award, which is made by a committee representative of the Royal Society, the Royal College of Surgeons of England, the Royal College of Surgeons in Ireland, the University of Edinburgh, and the University of Glasgow.

IT has been decided not to award any Nobel Prizes this year.

The Tenth International Ornithological Congress, which was to have been held in the United States in 1942 , has been indefinitely postponed.

A Malaria survey of Trinidad was recently begun under the supervision of Dr. Mark F. Boyd and Dr. W. G. Davis of the Rockefeller Foundation.

Messrs. Rowntrees, of York, have made a grant to Dr. F. C. Happold, reader in biochemistry in the University of Leeds, of $£ 150$ a year for two years for research work on nutritional problems.

Erratum.-It was stated in Nature of October 18, p. 457 , that Dr. E. Kodicek, who contributed a paper on post-war relief at the recent British Association meeting, was formerly lecturer in psychology in the University of Prague; this is incorrect. He held the position of head of the Department for Vitamins and Hormones at the University Clinic, Charles University, Prague. 